\title{
Editorial on the special issue "Ageing Populations, Reversing Early Retirement and the Economic Situation of Older People in Modern Societies"
}

\author{
Sandra Buchholz, Hans-Peter Blossfeld
}

This special issue of Comparative Population Studies addresses the economic wellbeing and employment chances of the population aged 50 years and older. One of the major challenges facing modern societies today and in future is a severe demographic ageing. Due to low fertility rates as well as rising life expectancy older people become an increasingly important part of the population in most developed countries. From both, the scientific as well as the political point of view, it is important to gain a better understanding about the economic situation of the older population as well as their labour market integration. The contributions of this special issue shed light onto these topics from different, complementing perspectives.

The first main aspect addressed by this special issue is the employment situation of older people in Europe and partly beyond. More and more, the labour markets of modern societies have to be able to integrate older workers more successfully. For several decades, most Western societies have relied on quite the opposite, namely on systematically pushing older workers out of employment (Kohli et al. 1991; Gruber/Wise 1999, 2004; Börsch-Supan 2000; Blossfeld et al. 2006; Ebbinghaus 2006; Blossfeld et al. 2011). The expansion of early retirement schemes was used in modern economies to relieve national labour markets since the early 1970s. Yet, the growing generational imbalance and the increasing share of older people have put pension systems of modern societies under pressure. Alongside this, the shrinking proportion of young workers will sooner or later result in increasing labour shortages in modern societies making it more and more important for competitive economies to maintain older people in employment instead of sending them into early retirement. Indeed, more recently a clear pension policy change can be observed in Western societies and governments, especially in European countries, have tried to increase the labour market attachment of older employees by retrenching early retirement options (see, for example, the "EU Lisbon Agenda 2010" as well as the "Europe 2020" targets). The first two contributions of this special issue by Ebbinghaus/ Hofäcker and Buchholz/Rinklake/Blossfeld dedicate themselves to the question of the effects of these recent policy attempts for reversing early retirement.

The article by Ebbinhaus/Hofäcker adopts an internationally comparative macro perspective on this issue. The authors show that there indeed has been a reversal of early retirement in most modern societies in the past years. However, at the 
same time there are significant differences between Western countries regarding the reversal of early retirement. Ebbinghaus/Hofäcker address the question of how these differences in reversing early retirement can be explained. For this purpose, the authors systematically review and discuss the role of diverse institutional factors by comparatively analysing selected European countries, the USA and Japan. By doing so, Ebbinghaus/Hofäcker make an important contribution to the existing literature of early retirement. Whilst previous research mainly aimed at discussing cross-national variations in using early retirement, a systematic comparative analysis of the differing success of reversing early retirement has been hardly addressed up to now. In their meta-analysis Ebbingshaus/Hofäcker identify four central factors which lead to a better understanding as well as a better explanation of the most recent reversal of retirement - namely pull, push, retrenchment, and stay factors. Based on their comparative analysis, Ebbinghaus/Hofäcker conclude that "Yet, reversing early retirement does not only require a gradual scaling back or abolishment of these institutional forces (retrenchment of pull factors), but it also depends on active ageing policies that help maintain older workers' employment." (p. 834).

The second article of this special issue by Buchholz/Rinklake/Blossfeld takes up this point. However, compared to Ebbinghaus/Hofäcker, this article does not addresses the reversal of early retirement from an international comparative macroperspective but from a micro-level perspective for one country, which is Germany. Germany is one of the countries which made massive use of early retirement in the 1970s, 1980s and 1990s. However, as other European countries, Germany has applied a significant pension policy change in the recent past by retrenching early retirement pathways and increasing financial penalties for early labour market withdrawal. Indeed, Germany is one of the countries showing a substantial reversal of early retirement and a comparatively strong increase of old age employment rates on the macro-level. Yet, in their longitudinal empirical study, Buchholz/Rinklake/ Blossfeld aim at studying the effects of the recent policy change on the individual micro-level. The authors specifically ask if there are parts of the older population that are not able to fulfil the new policy expectation to maintain longer working lives and they discuss possible consequences for social inequalities in old age. This empirical study is a continuation of the authors' research within the flexCAREER project, funded by a DFG research grant. The flexCAREER project aimed at analysing the effects of recent pension policy changes from an international comparative perspective. The detailed results for a total of ten modern societies have been published in an edited book volume in 2011 (Blossfeld et al. 2011). Though also the micro-level empirical study of Buchholz/Rinklake/Blossfeld shows that younger cohorts of older workers postpone their transition to retirement, it also becomes clear that the postponement of retirement is not accompanied by longer employment lives of the entire population of older people. In fact, especially lower qualified workers of recent cohorts are not able to meet the new expectation to maintain longer working lives, but are stuck in unemployment before reaching retirement. However, compared to previous cohorts of retirees, recent cohorts who become unemployed prior retirement are increasingly financially burdened for their "failure". Hence, these micro-level results of Buchholz/Rinklake/Blossfeld support the 
argument of Ebbingshaus/Hofäcker that a successful reversal of early retirement should not only rely on abolishing early retirement incentives (i.e. on reducing the "pull factors"), but needs to be accompanied by reforms supporting the employment chances of (all) older people (i.e. by the strengthening of "stay factors").

The third contribution of this special issue by Enge/hardt/Schmidt applies a different view on late labour market participation and labour market exits. Whilst international comparative research has broadly addressed the role of national institutions on old age employment rates and early retirement, Enge/hardt/Schmidt aim at understanding the role of other factors (potentially) influencing cross-national differences in late careers - namely, country-specific demographic, economic and labour-market structures. Specifically, Engelhardt/Schmidt ask if and how intragenerational competition, intergenerational substitution, level of education, unemployment rates, the extent of part-time work and the amount of service jobs influence late careers. Using data of the first two waves of SHARE and merging macro-level indicators from Eurostat, Engelhardt/Schmidt analyse labour market participation and transition to inactivity of older males in eleven European countries. Applying a multivariate multi-level framework, the empirical study of Engelhardt/Schmidt innovatively tries to disentangle and quantify the effect of country-specific factors and the relative impact of specific socio-demographic and socio-economic factors on international late careers. The results of Engelhardt/Schmidt indicate that late labour market participation and labour market exits are mainly driven by long-term unemployment and the share of highly educated among the elderly. Additionally, Enge/hardt/Schmidt find some evidence that intragenerational competition has an impact on late careers. Intergenerational competition, however, does not seem to affect an early labour market exit or late labour market participation.

While the first three articles of this special issue address older people's labour market integration, the fourth and final article by Kolb/Skopek/B/ossfeld sheds light onto a different and up to now largely neglected aspect, that is, older people's situation of wealth. Because housing is the core component of wealth among the older population in Europe (Skopek et al. 2012), in their empirical study Kolb/Skopek/ Blossfeld concentrate on housing inequalities among older people in Europe. Going beyond the labour market and studying wealth is essential, especially if one aims at understanding the (economic) situation of the older population. Current research (Jäntti 2006; Keister/Moeller 2000) has shown that the correlation between wealth and (labour market) income is less strong than expected. In particular for older people, wealth is important, especially once they withdraw from active labour market participation. By studying not only home ownership rates but also housing values, Kolb/Skopek/Blossfeld ask if there are two dimensions of inequalities in housing in Europe. Using SHARE data, the authors show that housing inequality in Europe indeed is a two-dimensional phenomenon. Additionally, their study highlights that especially for an appropriate understanding of the economic situation of older people, it is important to not only focus on (labour-market derived) income inequalities but also on their wealth position. Especially in times marked by welfare state and public pension retrenchments, accumulated wealth will become more and more important for the economic well-being of the older population. 


\section{References}

Blossfeld, Hans-Peter; Buchholz, Sandra; Hofäcker, Dirk (Eds.) 2006: Globalization, Uncertainty and Late Careers in Society. London/New York: Routledge.

Blossfeld, Hans-Peter; Buchholz, Sandra; Kurz, Karin (Eds.) 2011: Aging Population, Globalization and the Labor Market. Cheltenham. UK/Northampton, MA, USA: Edward Elgar.

Börsch-Supan, Axe/ 2000: Incentive effects of social security on labor force participation: Evidence in Germany and across Europe. In: Journal of Public Economics 78: 25-50.

Ebbinghaus, Bernhard 2006: Reforming Early Retirement in Europe, Japan and the USA. Oxford: Oxford University Press.

Gruber, Jonathan; Wise, David 1999: Social Security and Retirement around the World. Chicago: University Press.

Gruber, Jonathan; Wise, David 2004: Social Security Programs and Retirement around the World: Micro-Estimation. Chicago: University Press.

Jäntti, Markus 2006: Trends in the distribution of income and wealth: Finland 1987-1998. In: Wolff, Edward N. (Eds.): International Perspectives on Household Wealth. Cheltenham, UK/Northampton MA, USA: Edward Elgar: 295-326.

Keister, Lisa A.; Moeller, Stephanie 2000: Wealth Inequality in the United States. In: Annual Review of Sociology 26: 63-81.

Kohli, Martin; Rein, Martin; Guillemard, Anne-Marie; van Gunsteren, Herman 1991: Time for Retirement: Comparative Studies of Early Exit from the Labor Force, Cambridge/New York: Cambridge University Press.

Skopek, Nora; Kolb, Kathrin; Buchholz, Sandra; Blossfeld, Hans-Peter 2012: Einkommensreich - Vermögensarm? Die Zusammensetzung von Vermögen und die Bedeutung einzelner Vermögenskomponenten im europäischen Vergleich. In: Berliner Journal für Soziologie 22,2: 163-187.

Prof. Dr. Sandra Buchholz ( $₫)$, Prof. Dr. Hans-Peter Blossfeld. University of Bamberg, Chair of Sociology 1. Bamberg, Germany.

E-Mail: sandra.buchholz@uni-bamberg.de, hans-peter.blossfeld@uni-bamberg.de URL: http://www.uni-bamberg.de/en/soz1/professor-dr-sandra-buchholz/

URL: http://www.uni-bamberg.de/en/bamberg-graduate-schools/english/bagss/people/ faculty/hans-peter-blossfeld/ 


\section{Comparative Population Studies - Zeitschrift für Bevölkerungswissenschaft}

wWw.comparativepopulationstudies.de

ISSN: 1869-8980 (Print) - 1869-8999 (Internet)

Published by / Herausgegeben von

Prof. Dr. Norbert F. Schneider

Federal Institute for Population Research

D-65180 Wiesbaden / Germany

Managing Editor /

Verantwortlicher Redakteur

Frank Swiaczny

Assistant Managing Editor /

Stellvertretende Redakteurin

Katrin Schiefer

Language \& Copy Editor (English) /

Lektorat \& Übersetzungen (englisch)

Amelie Franke

Copy Editor (German) /

Lektorat (deutsch)

Dr. Evelyn Grünheid

\section{Layout / Satz}

Beatriz Feiler-Fuchs

E-mail: cpos@bib.bund.de

\author{
Scientific Advisory Board / \\ Wissenschaftlicher Beirat \\ Jürgen Dorbritz (Wiesbaden) \\ Paul Gans (Mannheim) \\ Johannes Huinink (Bremen) \\ Marc Luy (Wien) \\ Clara H. Mulder (Groningen) \\ Notburga Ott (Bochum) \\ Peter Preisendörfer (Mainz)
}

\section{Board of Reviewers / Gutachterbeirat} Martin Abraham (Erlangen)

Laura Bernardi (Lausanne) Hansjörg Bucher (Bonn)

Claudia Diehl (Konstanz)

Andreas Diekmann (Zürich)

Gabriele Doblhammer-Reiter (Rostock)

Henriette Engelhardt-Wölfler (Bamberg)

E.-Jürgen Flöthmann (Bielefeld)

Alexia Fürnkranz-Prskawetz (Wien)

Beat Fux (Zürich)

Joshua Goldstein (Rostock)

Karsten Hank (Köln)

Sonja Haug (Regensburg)

Franz-Josef Kemper (Berlin) †

Michaela Kreyenfeld (Rostock)

Aart C. Liefbroer (Den Haag)

Kurt Lüscher (Konstanz)

Dimiter Philipov (Wien)

Tomáš Sobotka (Wien)

Heike Trappe (Rostock) 